Indonesian Journal of Medicine (2018), 3(1): 44-48

https://doi.org/10.26911/theijmed.2018.03.01.06

\title{
The Difference of Work Posture in Musculo-skeletal Disorder Symptoms among Sales Women in the Department Store
}

\author{
Nailatun Nadrah'), Gerry Silaban'1), Taufik Ashar²) \\ 1)Department of Occupational Health and Safety, Faculty of Public Health, Universitas Sumatera \\ 2)Department of Environmental Health, Faculty of Public Health, Universitas Sumatera
}

\begin{abstract}
Background: Musculoskeletal complaints often occur in saleswomen who do awkward standing during work. Repair of standing position can reduce the risk of musculoskeletal pain. This study aimed to examine the effectiveness of corrective work posture on alleviating musculoskeletal disorder (MSD) symptoms among saleswomen in the department store.

Subjects and Method: This was a quasi experiment before and after with no control design conducted in Rantauprapat department store, North Sumatera. A sample of 30 sales women from the department store was selected for this study. The dependent variable was MSD scores as measured by Nordic Body Map (NBM). The independent variables were corrective work posture. The data before and after corrective work posture were compared and tested by t-test.

Results: There was a difference between poor and good posture in MSD symptoms among saleswomen in the Department Store. Saleswomen with poor posture had higher MSD symptoms (mean 64.45) than those with good posture (53.39), and it was statistically significant ( $\mathrm{p}=0.001$ ).

Conclusions: Saleswomen with poor posture has higher MSD symptoms than those with good posture.
\end{abstract}

Keywords: musculoskeletal disorders, work posture correction, Nordic Body Map

\section{Correspondence:}

Nailatun Nadrah. Department of Occupational Health and Safety, Faculty of Public Health, Universitas Sumatera, Medan, North Sumatera. Email: nailatunnadrah@gmail.com.

Mobile: +6281360661677

\section{BACKGROUND}

MSDs are one of the most serious health threats associated with work. Based on Health and Safety Executive (HSE) statistics in the UK about work-related musculoskeletal disorders, from 2016-2017, there have been 507,000 workers suffering from musculoskeletal disorders related to work, both new and old (HSE, 2017).

An awkward standing position is one of the factors that can cause pains in musculoskeletal. An awkward standing position is the position of the body that deviates significantly from its normal position while doing work can cause local mechanical stress on muscles, ligaments, and joints. This results in injuries to the neck, spine, shoulders, wrists, and is a risk factor that contributes to MSDs, and should be avoided. Work attitude is not natural or an awkward work attitude is a work attitude that causes the body part to move away from its natural position. The farther the position of the body part from the center of gravity, the higher the skeletal muscle complaints. Work attitude is not natural in general because of work mismatches with the ability of workers. An awkward posture is a deviation from the natural or neutral position of the body part. The natural position causes minimal pressure on the body. An awkward posture usually includes reaching overhead or behind the head, turning the waist, bending 
the body forward, back, or to the other side, squatting, kneeling, leaning on one leg and bending the wrist (Stack et al. 2016; Moore et al. 2011).

A body posture during work greatly affects the burden on the musculoskeletal system to minimize the risk of MSDs, workers who do some work should maintain proper and natural posture, if the load in the musculoskeletal system increases when the joints are in an awkward and extreme position, such as a bent or bent position, increasing the risk of a musculoskeletal disorder (Krzyskow, 2010).

Kinesiology is the study of the human body when performing body activity movements. This science is interdisciplinary, such as the anatomy of the human body (anthropotomy), neuromuscular physiology and biomechanics (the science of applying the mechanical aspects of the human body). The condition of the anatomical position means to stand upright, with your head, eyes and toes facing forward, both hands on your side with your hands open in front and both feet close together and pointing forward (Kuswana, 2016; Razza et al. 2017).

The term of a natural posture has become popular, in recent years. This shows the position of a healthy, desirable, or central limb. A neutral position or natural standing position is the center of the total range of motion, the wrist, showing the right hand, that is, according to the forearm (Plog, 2002; Kroemer, 2002).

An intervention study conducted by Lee et al. (2017), Wuriani et al. (2017), Pratama (2017), Natosba and Jaji (2017) by providing interventions related to ergonomics to workers also stated that there was an effect of improving position or providing intervention on complaints of MSDs.

A poor standing position at work will cause musculoskeletal complaints. Preliminary observation by Nordic Body Map (NBM) and also through interviews on 15 people obtained results, that all experienced MSDs with details of complaints there were 10 people (66.66\%) who felt pain in the upper and lower extremities, 8 people $(53.33 \%)$ were experienced pain in the shoulder, 13 people $(86.66 \%)$ had pain in the lower extremity. Complaints experienced by clerks come from unnatural work attitudes or improper standing position, standing with one leg, leaning against a wall or a display window repeatedly, causing complaints in the back, waist and lower extremities.

\section{SUBJECTS AND METHOD}

This was a quasi experiment. A sample of 30 sales women was selected for this study by purposive sampling. Data on MSD were obtained from NBM questionnaire. The dependent variable was MSD. The independent variables were poor standing position and good standing position. The data were analyzed by paired t-test.

\section{RESULTS \\ 1. Characteristics of the Study Subjects}

Table 1 shows the characteristics of the study subjects. Table 1 shows that out of 30 sales women, the average age was 23 years, BMI was 20.66, and tenure was 2.46 years.

Table 1. The Characteristic of Study Subjects

\begin{tabular}{lcccc}
\hline \multicolumn{1}{c}{ Variables } & Mean & SD & Minimum & Maximum \\
\hline Age & 23.00 & 3.51 & 18.00 & 30.00 \\
BMI & 20.66 & 1.77 & 18.26 & 24.98 \\
Tenure & 2.46 & 1.37 & 1.00 & 5.00 \\
\hline
\end{tabular}




\section{Musculoskeletal Complaints}

Table 2 showed the difference in musculoskeletal complaints between poor and good standing position. Table 2 shows all of the sales women with poor standing position

Table 2. Difference in Musculoskeletal Complaints between Poor and Good Standing Position

\begin{tabular}{llcccc}
\hline & & \multicolumn{2}{c}{ Poor Standing Position } & \multicolumn{2}{c}{ Natural Standing Position } \\
\cline { 3 - 6 } Waist & n & \% & n & \% \\
& Painless & 0 & 0 & 1 & 1.33 \\
& Mild & 4 & 13.33 & 2 & 6.67 \\
& Moderate & 0 & 0 & 27 & 90 \\
& Severe & 26 & 86.67 & 0 & 0 \\
Back & Painless & 0 & 0 & 0 & 0 \\
& Mild & 2 & 6.67 & 2 & 6.67 \\
& Moderate & 1 & 1.33 & 28 & 93.33 \\
& Severe & 27 & 90 & 0 & 0 \\
& Painless & 0 & 0 & 0 & 0 \\
& Mild & 0 & 0 & 0 & 0 \\
& Moderate & 0 & 0 & 30 & 100 \\
& Severe & 30 & 100 & 0 & 0 \\
& Painless & 0 & 0 & 0 & 0 \\
& Mild & 0 & 0 & 0 & 23.33 \\
& Moderate & 0 & 0 & 7 & 76.67 \\
\hline
\end{tabular}

\section{Bivariate analysis}

Table 3 showed the results of the paired $t-$ test analysis on the difference of work posture in the MSDs among sales women by paired t-test. There was a difference between poor and good posture in MSD experienced a pain on the calf and the leg. The percentage of sales women with poor standing position with severe waist musculoskeletal complaints was $86.67 \%$.

Table 3. The results of the paired t-test analysis on the difference of work posture in the MSDs among sales women

\begin{tabular}{lcccccc}
\hline & Mean & SD & 95\% CI & Minimal & Maximal & p \\
\hline Poor Standing Position & 64.45 & 3.43 & 2.56 to 4.22 & 55 & 69 & 0.001 \\
Good Standing Position & 53.39 & 3.63 & 2.49 to 4.53 & 44 & 61 & \\
\hline
\end{tabular}

\section{DISCUSSIONS}

MSDs was not a disease, it was a collection of symptoms which related to muscle tissue, tendons, ligaments, cartilages, nervous system, bone structure, and blood vessels. Musculoskeletal Complaints were complaints on parts of the skeletal muscles felt by a person, starting from very mild to very painful complaints (Tarwaka, 2004). Arnita (2006) stated that standing for a symptoms among saleswomen in the Department Store. Saleswomen with poor posture had higher MSD symptoms (mean 64.45) than those with good posture (53.39), and it was statistically significant $(\mathrm{p}=0.001)$. 
Stack et al. (2016) and Harrianto (2012) stated that one of the factors that could cause MSDs was work posture during working time. Body positions that deviate significantly from normal position while working could lead to local mechanical stress on muscles, ligaments, and joints.

Natural work posture or normal posture was an attitude or work posture that was in accordance with the shape of the body's anatomy, so that there was no shift or emphasis on the important parts of the body such as organs, nerves, tendons, and bones so that the workers became relaxed and it did not cause complaints on MSDs and other body systems (Lie, 2010). Moore et al. (2011) revealed that poor and neutral standing position used electromyography, this tool was sticked to the body part, if someone did an poor standing position, then it would affect the enhancement in the contraction of muscle activity, but if the respondent returned to natural position, the muscle activity would be decreased.

Suma'mur (2009) stated that working in non-ergonomic conditions could lead to various problems including pain, fatigue, and even accidents. Repairing the posture of the body while working could reduce the level of musculoskeletal complaints among worker. A theory of Gatam (2006) also stated that back pain was often caused by prolonged standing, improper standing position, non-ideal body postures, excessive activity, and trauma.

Tarwaka (2013) mentioned that it could be stated as good standing posture if the spine remained neutral like a lumbar lordosis so that the pressure on the vertebral disk was evenly distributed and the tension in the spinal ligament could be minimized.

This natural standing position was more directed at improving the habit of standing while working, so that when a salesperson stood in a natural position, it could reduce the complaints of MSDs. This study was supported by a study of Maisyaroh (2018) which analyze the stability scores and ergonomic interventions in Musculoskeletal disorders in Police members of Surakarta. The result showed that the provision of core stability and ergonomic interventions has a positive effect on decreasing Musculoskeletal disorders among Police members.

Eliminating worker exposure to all risk factors in physical workplaces was almost impossible to reduce the chance of injury due to a combination of risk factors that increase the likelihood of injury. For example, in situations which have a high exposure to awkward postures, changing body posture to neutral reduced the strength component as well. Small changes could make a big impact on the overall exposure profile of workers (Stack et al. 2016).

Based on the results of the study, it can be concluded that there was a difference between poor and good posture in MSD symptoms among saleswomen in the Department Store. Saleswomen with poor posture had higher MSD symptoms than those with good posture. Saleswomen with poor posture had higher MSD symptoms than those with good posture. It is suggested for the sales women to use the natural standing position, which was the straight position of head, and back with opened feet. Using the rest time to stretch the body and resting the feet by taking off the shoes. The sales women should use flat shoes or sandals when they were going to work, going home, and taking a break, so that it reduced the pressure on the feet.

\section{REFEERENCES}

$\overline{\text { Arnita (2006). Majalah farmacia edisi janu- }}$ 
Indonesian Journal of Medicine (2018), 3(1): 44-48

https://doi.org/10.26911/theijmed.2018.03.01.06

ari 2006. Halaman 23: http://www.majalahfarmacia.com/rubrik/one_ne ws.asp? IDNews $=13$.

Gatam M (2006). Deteksi Dini Penyakit Akibat Kerja. Jakarta: EGC.

Health And Safety Executive. Work-Related Musculoskeletal Disorders (WRMSDs) Statistics in Great Britain 2017.

Harrianto R (2012). Buku Ajar Kesehatan Kerja. Jakarta: buku Kedokteran EGC.

Kuswana WS (2016). Ergonomi Dan keselamatan Kesehatan Kerja. Cetakan kedua. Bandung: PT remaja Rosdakarya.

Kroemer K, Kromer A (2002). Ergonomi Office, USA and Canada: Taylor \& Francis e-Library: 66-69.

Krzyskow B (2010). Handbook of Occupational Safety and Health, New York: Taylor and Francis Group CRC Press.Lie M (2010). Postur tubuh yang ergonomis saat bekerja, diakses Februari 2018; https://merulalia.wordpress.com/2010/o8/30/posturtubuh-yangergonomis-saat-bekerja/.

Maisaroh RT (2018). Analisis core stability dan intervensi ergonomi pada gangguan Musculoskeletal di anggota kepolisian di Surakarta. (jurnal elektronik) diakses Mei 2018. eprints.ums.ac.id/61556/1/NASKAH\%20PUBLIKASI.pd.

Moore SMJT, Krajewski, Steiner LJ (2011). Practical Demonstrations of Ergonomic Principles, Pittsburgh: NIOSH.

Natosba J, Jaji (2016). Pengaruh Posisi Ergonomis Terhadap Kejadian Low
Back Pain (LBP) Pada Penenun Songket Di Kampung BNI 46. (Jurnal Elektronik) diakses November 2017; http://ejournal.unsri.ac.id/index.php/jk_sriwijaya/article/view/4237.Razza, Bruno MLC, Paschoarelli CC, Lucio JAC, Ulson, Silva D (2017). Ergonomics In Design Methods \& Techniques, New York: Taylor \& Francis Group CRC Press: 170-174.

Stack TLT, Ostrom, Wilhelsem CA (2016). Occupational Ergonomics APractical Approach, Canada: John Wiley \& Sons.

Suma'mur PK (2014). Higiene Perusahaan dan Kesehatan Kerja (Hiperkes). Cetakan ke-1, Jakarta: Sagung Seto: 417-419.

Tarwaka (2013). Ergonomi Industri DasarDasar Pengetahuan Ergonomi dan Aplikasi di Tempat Kerja, Cetakan 2. Surakarta: Harapan Press Solo: 329334 .

Tarwaka, Solichul B, Sudiajeng L (2004). Ergonomi untuk Keselamatan, Kesehatan Kerja dan Produktivitas. Cetakan pertama, Surakarta: Uniba Press.

Plog BA, Quinland PJ (2002). Fundamental of Industrial Hygiene, Fifth Edition, USA: National Safety Council.

Wuriani EMR, Affandi M (2017). Pengaruh Perbaikan Postur Kerja Terhadap Nyeri Muskuloskeletal Pada Perawat Di Klinik Kitamura Pontianak. Jurnal Elektronik diakses November 2017; http://journal.umy.ac.id/index.$\mathrm{php} / \mathrm{mm} /$ article/view/3679 